\title{
Camelot ... A Quest Or A Kingdom?
}

Is it possible for teachers, librarians, instructional technologists, information scientists, and materials producers to develop a unified commitment to the learning process? This question was raised at a technically superb presentation entitled “A Common Quest," presented at a special session of the 1972 National Convention of the Association for Educational Communications and Technology. Although the presentation was aimed at education in general with specific emphasis in the areas of elementary and secondary education, it seems equally imperative that higher education should address itself to the same question.

The producers tried to make King Arthur and his Camelot analogous to the educator and his school. As King Arthur searched for his impossible dream, the educator must search for his dream, i.e. the quest of the meaningful whole in a learner's education that will lend to a "theory of education."

Two experiences which had occurred earlier during the convention week had already instilled a healthy cynicism toward the viewing of this idealistic multisensory show. The first came from the realization that out of the nineteen members of the board of directors of this national association only one member has any direct ties with library and information science. In addition, out of the seven members on the executive committee, all are directly related to schools of education or audiovisual media service agencies. We recognize that this is an association for educational communications and technology; however, the quest of the educators' Camelot does not seem to have much representation in the hierarchy of this national body.

The second experience was based on impressions gathered from visits to two separate campuses. Both are of the same general size, composition, and purpose. The first visit was sponsored by the convention and the second was a personally initiated fishing expedition. The first campus sports a brand new educational center housing classrooms, faculty offices, reading rooms, an auditorium, a language laboratory, and an audiovisual learning center. When the director of learning services was questioned about the relationships between this center and the college library, he stated that he was not aware of any direct relationship. The two agencies seem to have different purposes. $\mathrm{He}$ described the learning center's purpose as one of direct, active use to the students. He envisioned the library as a more passive, storehouse operation.

The second visit was in direct contrast to the first. This campus has 
a brand new educational facility but it is called a "library." To be sure, audiovisual equipment was on hand, but it did not seem to be in constant use. The library administration and staff have been involved with a funded project for the past five years to study the undergraduate information system. They are very concerned with how the user seeks, receives, and interacts with information. They are extremely aware of the total informational needs which include nonprint media, but the staff seemed to emphasize the need to explore the total information needs of the campus.

These two views seem to be poles apart. They mirror two of the many attitudes one can observe in educational and library circles. One is that a specialist looks at education from his own perspective and feels it necessary to defend his own special interest area. And, second, one must analyze how many people use a system in an attempt to view information and educational needs as a whole. They analyze and serve needs rather than buy and dispense books, films, or tapes.

We, as librarians, must be prepared to recognize and develop realistic dreams that will challenge the kingdom builders. We need a round-table of teachers, librarians, instructional technologists, information scientists, and material producers working together to make Camelot a quest of the meaningful whole rather than a series of fragmented kingdoms.

Morell D. Boone 